\title{
Perguntas para o fim do mundo deles
}

Noá Araujo Prado ${ }^{1}$

\footnotetext{
1 artista multilinguagem, curadora, Mestra em Artes no Programa de Pós-graduação em Artes da Universidade federal do Ceará e integrante da V Turma da Escola de Audiovisual da Vila das Artes. Atualmente tem se interessado por obras artísticas que utilizam o hibridismo entre linguagens como suporte político de um ativismo implicado nos debates acerca da redistribuição de acessos para existências dissidentes
} 
Como fugir dos cativeiros estéticos? Como fugir dos cativeiros identitários? Como dialogar com o comum? Como criar comunas? Como fazer arte de quintal? Quem está comigo? O que podemos juntas? Que negociações são necessárias para a criação de um solo comum de compartilhamentos e trocas? Como desmontar a cena colonial entre as nossas? Como compartilhar processos em quintais? Como comunicar através do sensível? Como o sensível pode ser utilizado de forma bélica? Como o sensível pode também ser utilizado como forma de liberação e invenção? Inventar outros mundos é político? Inventar outros mundos é político? Inventar é político? Imaginar é político? Lombras estéticas podem ser políticas? Como inebriar o ativismo? Como entender a farra como projeto político? Como entender a dança como projeto político? Como inebriar o discurso pela forma? Onde começa o discurso e onde começa a forma? Quais os tons possíveis na comunicação com o outro? Como a arte pode desautomatizar? Como não reproduzir cativeiros estéticos e identitários? Como redistribuir os acessos? Como a arte pode ser pensada como instrumento de reparação e como podemos ser nossas próprias agentes da reparação? Como fundar entre nós de nós para nós em nossas comunidades expandidas? Como fundar comunas estéticas que não sejam bolhas? Como utilizar nosso repertório artístico para expandir a Grande Rachadura Interna do Cis-Tema? Como injetar na veia do delírio colonial pedagogias através do segredo? O mistério é político? O segredo é político? Como não cristalizar as identidades? E como não entendêlas como cristalinas? Como se comunicar na opacidade? Como fundar rotas de ação que não sejam desenhadas em linhas retas? Existe artivismo onírico? A luta política pode ser traçada através da lógica dos sonhos? Existe artivismo surrealista? Existe artivismo bêbado? É possível um artivismo lisérgico? Minhas pautas cabem na minha dança? Minha dança dá conta das minhas pautas? Como pautar os sonhos? 